\title{
Alloantibodies to HLA Class 1 Antigens Detected in Multiparous Women of African Descent Are Significantly Associated with Age, ABO/Rh Blood Groups and Parity
}

\author{
Zaccheaus. A. Jeremiah ${ }^{1 *}$, Justina. E. Oburu ${ }^{2}$ and Fiekumo.I. Buseri ${ }^{1}$ \\ ${ }^{1}$ Haematology and Blood Transfusion Sciences Unit, \\ Department of Medical Laboratory Sciences, College of Health Sciences, Niger Delta University, \\ Wilberforce Island, Bayelsa Sate, Nigeria \\ ${ }^{2}$ Department of Haematology and Blood Transfusion, University of Port Harcourt Teaching Hospital, \\ Port Harcourt, Nigeria. \\ *Corresponding Author \\ Zaccheaus. A. Jeremiah \\ Haematology and Blood Transfusion Sciences Unit, \\ Department of Medical Laboratory Sciences, \\ College of Health Sciences, \\ Niger Delta University, \\ Wilberforce Island, Bayelsa Sate \\ Nigeria \\ Email: zacjerry@yahoo.com
}

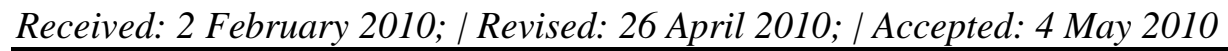

\begin{abstract}
The prevalence of alloantibodies to HLA class 1 antigens has not been reported in Nigeria and West Africa. This study was aimed at determining the prevalence of anti- HLA class 1 antibody and also evaluates its association with age, blood groups, parity and ethnicity. A cross section of apparently healthy adult multiparous women from the University of Port Harcourt Teaching Hospital, Nigeria were screened for alloantibody to HLA class 1 antigens using the GTI PakPlus $®$ qualitative solid phase ELISA reagent. Their $\mathrm{ABO} / \mathrm{Rh}$ blood groups were also determined using standard haemagglutination tube technique. The prevalence of alloantibodies to HLA class 1 antigen was $22.0 \%$. ABO/Rh blood groups were obtained as follows. O Rh D ${ }^{+}(68 \%), \mathrm{O}_{\mathrm{Rh} \mathrm{D}}^{-}(4.0 \%) \mathrm{A} \mathrm{RhD}^{+}(14.0 \%), \mathrm{A} \mathrm{Rh} \mathrm{D}^{+}(2.0 \%), \mathrm{B} \mathrm{Rh} \mathrm{D}^{+}(10 \%)$ and $\mathrm{AB} \mathrm{Rh}^{-}$ $(2.0 \%)$. Statistical analysis using Fisher's Exact test revealed that age, parity and ABO/Rh blood groups exerted significant influence on the prevalence of anti-HLA Class I antibodies (Fisher's Exact test $=14.188$, $\mathrm{P}<0.001 ; 10.891, \mathrm{P}<0.01$ and $9.046, \mathrm{P}<0.05$ for age, parity and blood groups respectively). No association was found between ethnicity and HLA class 1 antibody. This study has revealed a high prevalence rate of HLA class 1 antibodies. A significant observation of this study was that factors like age, parity and ABO/Rh blood groups play prominent roles in the development of these cytotoxic antibodies.
\end{abstract}

Keywords: HLA Class 1 antibodies; ABO/Rh blood groups; parity; multiparous women. 


\section{Introduction}

The human leucocytes Antigen system (HLA) consists of a family of cell surface polymorphic molecules involved in the presentation of antigen to $\mathrm{T}$ cells and therefore play a central role in the induction and regulation of immune responses[1,2]. HLA molecules are also known to be involved in the pathogenesis of certain autoimmune and infectious diseases and they have an important influence on the outcome of solid organ, hematopoietic stem cell transplantation and are responsible for some of the various clinical complications of blood transfusion [1].

HLA specific antibodies may be produced in any situation that exposes the host to the HLA alloantigen including pregnancy, transplantation blood transfusion and planned immunization [3]. Cytotoxic HLA antibodies can be identified in approximately $20 \%$ of human pregnancies. The antibodies produced are normally multispecific, high titer, high affinity and of the $\operatorname{IgG}$ class. Although these $\operatorname{IgG}$ antibodies can cross the placenta, they have not been shown to be harmful to fetus [4]. In contrast, the majority of HLA antibodies found in multitransfused patients is multispecific $\operatorname{IgM}$ and $\mathrm{IgG}$ and is mostly directed at public epitopes. The recent introduction of leucocytes-depleted blood components may lead to reduction in alloimmunization in naïve recipients but it may not be very effective in preventing alloimmunization in an already sensitized recipient.( i.e. women who have become immunized as a result of pregnancy) [5].

Formation of HLA antibodies are among the non-infectious risk that has been identified and the typing and identification of these antibodies for histocompatibility are among the routine laboratory investigations assayed for donated blood in developed countries [6], however, this is a far cry in this part of the world as these investigations are not being practiced even in our tertiary health care facilities. Multiparous women on the other hand are very good long term blood donors but owing to the multiple pregnancies, they may develop higher than usual titers of HLA antibodies to the fetal HLA antigens of paternal origin. These multiparous women can also be a source of producing anti- HLA antibodies.
Presently, there is paucity of information on the prevalence of HLA antibodies in Nigeria. This study was therefore conducted primarily to determine the frequencies of alloantibody to HLA class 1 antigen in our multiparous African women population and then to evaluate the risk factors associated with its production.

\section{Materials and Methods}

\subsection{Subjects}

One hundred apparently healthy women who had histories of having been pregnant for at least twice and had ceased having children for the past one year were recruited randomly into this cross sectional study between February to June 2009. All the women were staff of the University of Port Harcourt Teaching Hospital, Nigeria (UPTH). Institutional ethical approval for this study was given by the Department of Medical Laboratory Sciences, Rivers State University of Science and Technology, Port Harcourt. All the participants gave their written informed consents before blood samples were collected from them. 3 milliliters of blood was collected through the antecubital vein into an EDTA container. The blood groups were determined and the plasma separated through centrifugation and archived for HLA antibodies ELISA assay.

The ABO and Rhesus blood groups were determined using the standard tube method of forward grouping with anti-A, anti-B, anti-AB. and anti-D antisera obtained from Biotic, Ipswich, UK. Test tubes were labeled according to the number of test samples, anti-A, anti-B, anti-AB, anti-D and controls. A 2\% suspension of the subject's red cell was made. 2 drops of the antisera was added to the tubes labeled. Then 2 drops of the $2 \%$ suspension of the subjects' red cells were added to each tube. It was mixed and centrifuged at $1,500 \mathrm{rpm}$ for 20 seconds. Positive reaction was detected by observing the agglutination after resuspending the cells button and confirmed microscopically. A negative reaction was confirmed with indirect agglutination technique using 20\% Bovine albumin and AHG reagent at both room temperature and $37^{\circ} \mathrm{C}$ before negative result was recorded. No $\mathrm{D}^{\mathrm{u}}$ was encountered throughout the study.

(c) 2010 by NWPII. All rights reserved. 
The GTI PakPlus @ reagent kit bought directly from GTI Diagnostics, Waukesha, WI, USA was used for the detection of the HLA class 1 antibodies. The GTI PakPlus test was performed according to the manufacturer's instructions. Briefly, $50 \mu 1$ of control or test serum, diluted 1:2 with specimen diluents solution was added to duplicate wells in a microtest plate and incubated for 40 mins at $37^{\circ} \mathrm{C}$. The plate was then washed three times with $300 \mu l$ of wash solution per well and $50 \mu \mathrm{l}$ of an alkaline-phosphatase-conjugated, affinity purified goat antibody to human immunoglobulin (1 in 10 dilution) was added to each well. After incubation for 40 minutes at $37^{\circ} \mathrm{C}$ and three additional washes, $100 \mu \mathrm{l}$ of p-nitro phenyl phosphate solution diluted I in 100 in the enzyme substrate buffer was added and the mixture was incubated in the dark at room temperature $\left(18\right.$ to $\left.22^{\circ} \mathrm{C}\right)$. The reaction was stopped after 30 minutes by the addition of $100 \mu 1$ ELISA stop solution and the absorbance of each well at a wavelength of $405 \mathrm{~nm}$ was measured in an ELISA plate reader (STAT FAX 2100, Awareness Technology, USA ). Test wells having optical densities (ODs) equal to or greater than twice the mean OD of the negative control wells were regarded as positive. Whenever the OD reading of either of the duplicate test wells exceeded $20 \%$ of the mean OD of the two wells, the test of that serum was considered invalid and was repeated.

\subsection{Statistical Analysis}

Statistical analysis was performed with statistical software (SPSS version 12.0 for windows, Chicago, IL). Results were expressed as mean and standard deviation for age and parity, frequency distributions for $\mathrm{ABO} / \mathrm{Rh}$ blood groups and HLA antibodies. Fisher's exact test was used to test the association between HLA antibodies and other parameters Results of the statistical tests were deemed significant if the two-tailed probability ( $\mathrm{p}$ value) was $\leq 0.05$.

\section{Results}

A total of one Hundred (100) multiparous women randomly selected from among staff of the University of Port Harcourt Teaching Hospital
(UPTH), Nigeria were invited to participate in the study. Their demographic characteristics are as shown in table 1 .

Table 1: Demographic characteristics of the 100 participants

Characteristics $\quad$ Frequency (\%)

\begin{tabular}{ll}
\hline Age Groups (years) & \\
\hline $25-34$ & 28.0 \\
$35-44$ & 40.0 \\
$45-54$ & 26.0 \\
$55-$ abve & 6.0 \\
Parity & \\
2 & 18.0 \\
3 & 28.0 \\
4 & 26.0 \\
5 & 12.0 \\
6 & 8.0 \\
8 & 4.0 \\
9 & 2.0 \\
11 & 2.0 \\
Ethnicity & \\
Ijaw & 32.0 \\
Ikwere/Etche & 26.0 \\
Ekpey/Ogba & 16.0 \\
Igbo & 14.0 \\
Yoruba & 6.0 \\
Akwa-Ibom & 6.0 \\
\hline
\end{tabular}

The frequency of the $\mathrm{ABO} / \mathrm{Rh}$ blood groups and HLA class 1 antibodies is as shown in table 2 . Blood group $\mathrm{O} \mathrm{Rh} \mathrm{D}^{+}$accounted for $68.0 \%, \mathrm{~A} \mathrm{Rh}$ $\mathrm{D}^{+}(14.0 \%), \mathrm{B} \mathrm{Rh} \mathrm{D}{ }^{+}(10.0 \%), \mathrm{O} \mathrm{Rh} \mathrm{D}^{-}(4.0 \%), \mathrm{A}$ Rh D-(2.0\%), and AB Rh D- (2.0\%).

The prevalence of HLA class 1 antibodies was $22.0 \%$. Table 3 shows the mean values of the age and parity of the participants. Their mean age was $40.64 \pm 8.4$ years. 
In order to determine the influence of age, parity, ethnicity and blood groups on the prevalence of anti-HLA class I antibodies, the data were subjected to Fisher's exact test analysis as shown in table 4. It was observed that age, parity and blood groups exerted significant influence on the prevalence of HLA class I antibodies (Fisher's exact test. 14.188, $\mathrm{P}<0.001 ; 10.891, \mathrm{P}<$ 0.01 and $9.046, \mathrm{P}<0.05$ for age, parity and blood groups respectively) while ethnicity was not fond to exert any influence on the anti-HLA class I prevalence.

Table 2: Frequency of ABO and Rhesus blood groups and HLA Class I antibodies

\begin{tabular}{lcc}
\hline \multicolumn{1}{c}{ Characteristics } & Number & Percentage (\%) \\
\hline ABO and Rh Blood groups & 2 & 2.0 \\
\hline $\mathrm{A}^{-}$ & 14 & 14.0 \\
$\mathrm{~A}^{+}$ & 2 & 2.0 \\
$\mathrm{AB}^{-}$ & 10 & 10.0 \\
$\mathrm{~B}^{+}$ & 4 & 4.0 \\
$\mathrm{O}^{-}$ & 68 & 68.0 \\
$\mathrm{O}^{+}$ & & \\
Anti-HLA-antibodies & & \\
Anti-HLA class I antibodies & 22 & 22.0 \\
Positive & 78 & 78.0 \\
Negative & & \\
\hline
\end{tabular}

Table 3: Mean values of the age and parity of the participants

\begin{tabular}{llll}
\hline Parameters & Mean $( \pm$ SD) & Minimum & Maximum \\
\hline Age (years) & $40.64( \pm 8.4)$ & 26 & 59 \\
Parity & $4.0( \pm 1.9)$ & 2 & 11 \\
\hline
\end{tabular}

\section{Discussion}

Human Leucocytes antigens (HLA) class 1 molecules are expressed on the surface of almost all nucleated cells. The HLA system is known to be the most polymorphic in humans [7]. The distribution and frequency of HLA antigens vary greatly among different ethnic groups and this diversity has been postulated to evolve under unique selective pressure in different geographical areas[8]. HLA typing sera are mainly obtained from multiparous alloimmunized women pregnancies or transplants [8].
This study describes the frequencies of alloantibody to HLA class 1 antigens in Nigerian women with a history of frequent pregnancies. The study is unique as there are no reports with comparable information in Nigeria and even West Africa so far. The main findings of this study are: (1) the detection of HLA class I antibodies in $22 \%$ of the women. (2) Significant influence of the number of previous pregnancies on the occurrence of HLA antibodies. (3) The significant influence of age and $\mathrm{ABO} / \mathrm{Rh}$ blood groups on the occurrence of HLA antibodies. 
Table 4: Influence of age, parity, ethnicity and blood groups on the prevalence of HLA class I antibodies.

\begin{tabular}{ll}
\hline Variables & $\begin{array}{l}\text { Anti-HLA Class } 1 \text { antibodies } \\
\text { Positive }(\%)\end{array}$ \\
\hline Age (years) & \\
\hline $25-34$ & $6(21.4)$ \\
$35-44$ & $0(0)$ \\
$45-54$ & $14(53.8)$ \\
55 and above & $2(33.3)$ \\
Fisher's Exact Test & $14.188^{* * *}$ \\
Parity & \\
2 & $0(0)$ \\
3 & $4(14.3)$ \\
4 & $(23.1)$ \\
5 & $4(33.3)$ \\
6 & $2(25.0)$ \\
8 & $2(50.0)$ \\
9 & $29(100.0)$ \\
11 & $2(100.0)$ \\
Fisher's Exact Test & $10.891^{* *}$ \\
Ethnic group & \\
Ijaw & $10(31.3)$ \\
Ikwerre/Etch & $6(23.1)$ \\
Ekpeye/Ogba & $0(0)$ \\
Igbo & $2(28.6)$ \\
Yoruba & $2(33.3)$ \\
Akwa Ibom & $0(0)$ \\
Fisher's Exact test $=$ & $4.300^{\text {ns }}$ \\
ABO/Rh blood groups & \\
$\mathrm{A}^{-}$ & $0(0)$ \\
$\mathrm{A}^{+}$ & $6(42.9)$ \\
$\mathrm{B}^{+}$ & $0(0)$ \\
\hline & $2(20.0)$ \\
& $4(100)$ \\
& $10(14.7)$ \\
& $9.046^{*}$ \\
& \\
\hline
\end{tabular}

The $22 \%$ prevalence of anti-HLA class I antibodies obtained in this study is very similar to what was obtained among multiparous women in
Korea and India where a prevalence of $18.5 \%$ and $13.4 \%$ were reported respectively [5, 9]. Neonatal alloimmune thrombocytopenia (NAIT) results from human platelet antigen (HPA) incompatibility, with a reported incidence of 1 in 1000 or I in 5000 [10,11]. HLA antibodies have been reported to occur in up to one third of pregnancies, even though the fetus in usually protected by the mechanism of blocking antibodies and placental filtration [12]. HLA antigens have only rarely been implicated as a cause of NAIT [13]. HLA antibodies have also been implicated as a cause of platelet refractoriness [12-16]. It follows therefore that the detection of HLA antibodies in multiparous women is of much clinical significance.

Another significant finding in this study is the association between HLA class 1 antibodies and $\mathrm{ABO} / \mathrm{Rh}$ blood groups. In randomized trial by Schlitchter et al [17]. Patients routinely transfused with ABO-mismatched platelets were more likely to develop both HLA and platelet specific antibodies, accompanied by an earlier onset and higher incidence of clinical platelet refractoriness. It follows that routine transfusion of $\mathrm{ABO}$ incompatible platelets can promote HLA alloimmunization. The significant association between age and HLA antibodies is yet to be fully understood as there are no reports to support this finding. Possible explanations could be that the majority of the women who participated in this study were between the ages of $35-54$ years. The highest prevalence of anti - HLA class 1 antibodies $(53.8 \%)$ occurred among women age 45-54 years followed by $33.3 \%$ among 55 years and above. There was zero prevalence among women of $35-44$ years. The lowest prevalence (21.4\%) occurred among 25-34 years group. It was also observed that HLA antibodies did not occur in women with parity 2 . The occurrence of HLA antibodies progressed from $14.3 \%$ with parity 3 to $33.3 \%$ with parity 5 and then to $100 \%$ for women with parity 9 and 11 . Fisher's exact test was statistically significant $(\mathrm{P}<0.001)$ indicating that age and parity have a combined influence on the development of HLA class 1 antibodies. Overall, the statistics indicated that the possibility of making HLA antibodies increase with multiparity, age and $\mathrm{ABO} / \mathrm{Rh}$ blood groups. 
Routine transfusion of $\mathrm{ABO}$ incompatible platelets should be discouraged as this could result to decreased post transfusion recovery, HLA alloimmunization and platelet refractoriness.

\section{Acknowledgement}

We sincerely wish to thank GTI diagnostics, Waukesha, USA for giving us rebates which enabled us to purchase the GTI PakPlus reagent kit at a subsidized rate, without which this work would not have been possible. We also thank the female staff of UPTH who volunteered themselves for this study.

\section{References}

1. Navarrete CV. Human Leucocye antigens In. Practical transfusion medicine Michael FM, Derwood HP (Eds). $1^{\text {st }}$ Edition. United Kingdom: Blackwell Science Company. 2002 pp $36-49$

2. Murphey CL, Forsthuber TG. Trends in HLA antibody screening and identification and their role in transplantation. Expert Rev Clin Iminunol 2008; 4: 391-399

3. Mason Y, Heine U, Stuhmiller GM, Human Leucocyte antigens. In: Immunohematology principles and practice. $2^{\text {nd }}$ Ed Quinley ED (Ed). Philadelphia USA: Lippincott- Raven publishers. 1998 pp 376 - 379.

4. Little A, Steven GE, Alejandro M. Histocompatibility. In: Post graduate haematlogy Victor H, Daniel C, Edward GD (Eds). $5^{\text {th }}$ Edition. Massachusets, USA: Blackwell publishing. 2005 pp. 395-413.

5. Pitchappan RM, Amutha S, Mahendran V, Brahmajohi V, Shankar UK, Shantar R. Frequency of HLA antibodies in South India. Biosciences 1993; 18:373-380

6. Kleinman S, Chan P, Robillard P. Risk associated with transfusion of celllular blood components in Canada. Tranfus Med. Rev 2003; 17: $120-162$.
7. Klein J, Sato A. The HLA system. First of two years. New Engl J Med 2000; 343: 702 709.

8. Choo SY. The HLA system: genetics immunology, clinical testing and clinical implications Yonsei Med J 2007; 48 11-23

9. Song EY, Kini SM, Kim BC, Han KS, Park $\mathrm{MH}$. Positive rate of HLA Class I antibodies in multiparous Korean women. Korean J Clin Pathol 2000; 20:210 - 214.

10. Muller-Eckhardt C, Kiefel V, Grubert A. et al. 348 cases of suspected alloimmune thrombocytopenia Lancet 1989; 1:363.

11. Blanchette VS, Chen L, Solomon de Friedberg $\mathrm{Z}$ et al. Alloimmunization to the $\mathrm{P} 1{ }^{\mathrm{AI}}$ platelet antigen: results of a prospective study. $\mathrm{Br} J$ Haematol 1990; 74:209

12. Grainger JD, Morrel G, Yates J, Deleacy D. Neonatal alloimmune thrombocytopenia with significant HLA antibodies. Arch Dis Child Fetal Neonatal Ed 2002; 86: F200 -F201.

13. Legler TJ, Fischer I, Dittman $\mathrm{J}$ et al. Frequency and causes of refractoriness in multiply transfused. Ann Hematol 1997;74:185-9

14. Brubaker DB, Romine M. Relationship of HLA and platelet reactive antibodies in alloinmunized patients' refractory to platelet therapy. Am J Hematol 1987;26:341-52

15. Marin L, Torio A, Muro M et al. Alloimmune neonatal neutropenia and thrombocytopenia associated with maternal anti-HNA - I a, HPA-3b and HLA antibodies. Pediatric Allergy Immunol 2005; 16:279-82.

16. Boehlen F, Kaplan C, de Moerloose P. Severe neonatal alloimmune thrombocytopenia due to HLA and anti-HPA-3a. Vox Sang 1998;74:201 $-4$

17. Schlichter SJ, Davis K, Enright $\mathrm{H}$ et al. Factors affecting post transfusion platelet increments, platelet refractoriness and platelet transfusion intervals in thrombocytopenic patients. Blood 2005; 105:4106-4111. 